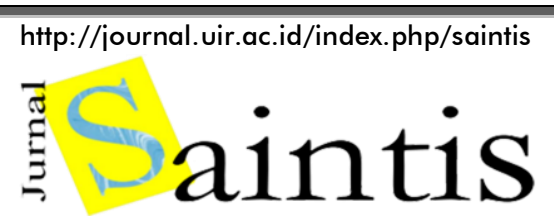

\title{
Analisis Hidrologi Model Soil Moisture Accounting Menggunakan Program HEC-HMS \\ (Studi Kasus : DAS Rokan AWLR Pasir Pangaraian)

\author{
Hydrological Analysis of the Soil Moisture Accounting Using the HEC-HMS
} \\ (Cases of Study: DAS Rokan AWLR Pasir Pangaraian)
}

\section{Gopal Adya Ariska ${ }^{1, *}$, Yohanna Lilis Handayani ${ }^{1}$, Bambang Sujatmoko ${ }^{1}$ \\ ${ }^{1}$ S1 Teknik Sipil, Universitas Riau, Kampus Bina Widya Jl. HR Soebrantas KM 12,5 Pekan baru, Indonesia}

\author{
* Penulis korespondensi : gopal.adya@student.unri.ac.id \\ Tel.: +6282384049024; Fax.: - \\ Diterima: 1 April 2020; Direvisi: 27 April 2020; Disetujui: 28 April 2020. \\ DOI: 10.25299/saintis2020.vol20(01).4753
}

\section{Abstrak}

Hidrologi suatu Daerah Aliran Sungai (DAS) rumit untuk diprediksi karena kekurangan data dan membutuhkan biaya yang mahal. Pada penelitian ini mengambil lokasi di sub DAS Rokan Hulu stasiun Pasir Pengaraian yang hampir setiap tahun terjadi banjir. Perencanaan dan pengolahan sumber daya air di suatu wilayah daerah aliran sungai sangat penting, maka dari itu perlunya mengetahui karakteristik suatu DAS. Perencanaan dan pengolaan sumber daya air memerlukan data debit aliran yang lengkap. Pada sub DAS ini data hujan, data debit dan data klimatologi menggunakan periode data sepuluh tahun yaitu dari tahun 2008-2017. Pemodelan hidrologi dilakukan pendekatan dengan beberapa metode, salah satunya metode soil moisture accounting di program HEC-HMS yang mana metode tersebut mensimulasikan suatu pergerakan air pada vegetasi, permukaan tanah dan di bawah permukaan tanah. Penyusunan periode kalibrasi dan verifikasi disusun dalam sembilan skema yang diharapkan mampu menghasilkan hasil yang paling optimal. Sembilan skema untuk Kalibrasi dan Verifikasi ini menggunakan metode objective function yaitu percent error in discharge volume. Skema yang paling optimal adalah skema VII (7 tahun kalibrasi 3 tahun Verifikasi), dengan nilai verifikasi 10,1\%"Baik" dan Kalibrasi 0,0\% "Sangat Baik".

Kata Kunci: Soil Moisture Accounting, Recession - Ratio to Peak, Error Volume, HEC-HMS

\begin{abstract}
The hydrology of a watershed is difficult to predict because of the lack of data and requires high costs. In this study taking location in the Rokan Hulu sub-watershed, Pasir Pengaraian station Almost every year flooding occurs. Planning and management of water resources in a watershed is very important and therefore it is necessary to know the characteristics of the watershed. Planning and management of water resources require complete data. in this sub-watershed rainfall data, discharge data and climatology data use a ten-year data period from 2008-2017. Hydrological modeling is approached with several methods, one of them is soil moisture accounting method in the HEC-HMS program where the method simulates a movement of water on vegetation, soil surface and below ground level. The preparation of the calibration and verification periods arranged in nine schemes is expected to produce the most optimal results. The nine schemes for Calibration and Verification use the objective function method, which is the percentage error in discharge volume. The most optimal scheme is the scheme VII (7 years calibration 3 years Verification), with a verification value of 10.1\% "Good" and Calibration 0.0\% "Very Good".
\end{abstract}

Keywords: Soil Moisture Accounting, Recession - Ratio to Peak, Error Volume, HEC-HMS

\section{PENDAHULUAN}

Siklus hidrologi merupakan gambaran keseluruhan tentang pengalihragaman massa air dalam suatu kawasan atau Daerah Aliran Sungai (DAS). Perencanaan dan pengelolaan sumber daya air di suatu wilayah atau daerah aliran sungai memerlukan data debit aliran yang lengkap dan panjang.

Salah satu model analisa hidrologi adalah model soil moisture accounting. Model soil moisture accounting dapat digunakan untuk mensimulasi debit dalam periode waktu yang panjang. Model ini mensimulasikan perilaku debit di sungai.
Penggunaan model HEC-HMS diharapkan mampu menirukan sistem DAS yang mempunyai variabilitas sistem DAS dan karakter masukan (input) yang mempunyai ruang dan waktu yang sangat tinggi.

Daerah aliran sungai yang diteliti adalah Daerah Aliran Sungai Rokan AWLR Pasir Pengaraian. Daerah Aliran Sungai AWLR Pasir Pengaraian merupakan sub DAS yang berada pada Wilayah Sungai (WS) Rokan tepatnya pada sungai Batang Lubuh yang mengalir ke sungai Rokan.

Sungai Batang Lubuh merupakan salah satu sungai yang mengalir di Kabupaten Rokan Hulu. Sungai ini merupakan sungai terbesar di Kabupaten 
Rokan Hulu. Hampir setiap tahun terjadi banjir, khususnya pada musim penghujan. Hal ini diperkirakan karena terjadi pendangkalan sungai yang salah satu penyebabnya adalah runtuhnya tebing sungai [1].

Banjir yang terjadi pada suatu wilayah DAS, disebabkan karena berkurangnya luas daerah resapan air akibat perubahan tata guna lahan yang tidak terencana dan terpola [2].

Kebijakan atau perlakuan pengolahan sub DAS Pasir Pengaraian agar memenuhi tujuan yang diinginkan perlu dilakukan kajian permodelan yang akurat. Permodelan hidrologi memerlukan ketepatan metode analisis model yang sesuai dengan karakteristik sub DAS ini.

Teguh Marhendi dalam penelitiannya yang berjudul "Analisis low flow menggunakan model HEC-HMS 3.1 untuk kasus SUB DAS Kranggan" menunjukkan bahwa parameter surface capacity dan max infiltration rate sangat sensitive terhadap perubahan yang terjadi pada sub DAS Kranggan [3].

\section{Konsep Hidrologi}

Secara keseluruhan jumlah air di bumi ini relatif tetap dari masa ke masa. Air di bumi mengalami suatu siklus melalui suatu rangkaian peristiwa yang berlangsung terus-menerus. Serangkaian peristiwa tersebut dinamakan siklus hidrologi [4].

\section{Daerah Aliran Sungai}

Departemen Kehutanan memberikan pengertian bahwa Daerah Aliran Sungai adalah suatu daerah tertentu yang bentuk dan sifat alamnya sedemikian rupa, sehingga merupakan kesatuan dengan sungai dan anak-anak sungainya yang melalui daerah tersebut dalam fungsinya untuk menampung air yang berasal dari curah hujan dan sumber air lainnya, dan kemudian mengalirkan melalui sungai utamanya (single outlet). Air hujan yang jatuh didalam DAS akan mengalir menuju sungai utama yang ditinjau, sedang yang jatuh diluarnya akan mengalir ke sungai lain disebelahnya [5].

\section{Definisi Model Hidrologi}

Suatu model hidrologi diperlukan untuk memodelkan kondisi atmosferik suatu daerah aliran yang kompleks dalam bentuk jaringan aliran. Daerah aliran (watershed atau catchment area) adalah daerah yang menyediakan sebuah sistem sungai dan reservoir.

\section{Penyusunan Basin Model}

Model Soil Mousture Accounting (SMA) dipolakan oleh Leavesley dengan nama sistem permodelan hujan-limpasan Leavesley dan dijelas dengan jelas oleh Bennett [6]. Suatu model tersebut mensimulasikan suatu pergerakan air lewat dan penyimpanan air pada vegetasi, pada permukaan tanah di profil tanah dan di lapisan permukaan air. Model SMA menghitung limpasan permukaan basin, aliran permukaan air, kehilangan karena evapotranspirasi dan perkolasi dalam melewati keseluruhan basin. Faktor iklim menyangkut hubungan antara hujan dan evapotranspirasi [7].

$$
\text { Metode Soil Moisture Accounting }
$$

menggunakan 5 layer untuk menampilkaan suatu dinamika pergerakan air diatas permukaan dan didalam tanah. Layer tersebut diantaranya canopy interception, surface depression storage, soil, upper groundwater, soil profil storage dan lower groundwater bisa dilihat pada Gambar 1

Metode SMA di HEC-HMS adalah onedimensional, semi-distributed yang merupakan representasi dari proses tanah. model hidrologi onedimensional hanya membiarkan air mengalir satu arah selama time-step. Model SMA di HEC-HMS adalah yang paling fleksibel dan luas pada metode loss yang tersedia untuk software HEC-HMS.

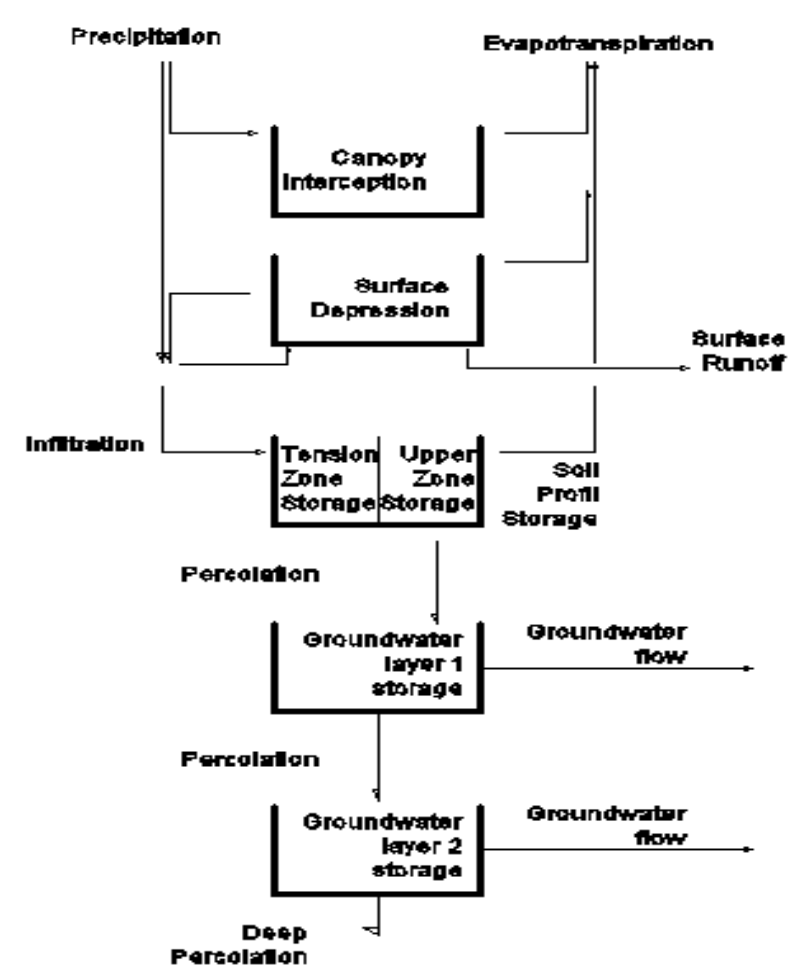

Gambar 1. Algoritma Soil Moisture Accounting

Tujuan dari penelitian adalah menganalisis keandalan metode Soil Moisture Accounting untuk memprediksi debit sungai di sub DAS Stasiun Pasir Pangaraian.

Output model yang terbaik ditunjukkan dengan nilai korelasi yang tinggi dan selisih error antara debit dan debit tercatat yang paling rendah [8]. Selisih volume atau volume error (VE) aliran adalah nilai yang menunjukkan perbedaan volume terukur selama proses simulasi [9]. 


\section{METODOLOGI}

Lokasi Penelitian berada di sub DAS Stasiun AWLR Pasir Pengaraian, yang secara administrasi terletak Desa Pasir Pangaraian, Kecamatan Rambah, Provinsi Riau, dengan letak geografis $00^{\circ} 35^{\prime} 24^{\prime \prime} \mathrm{LU}$ dan 101 $11^{\prime}$ 46" BT (Badan Pusat Statistik Pekanbaru) dapat dilihat pada Gambar 2.

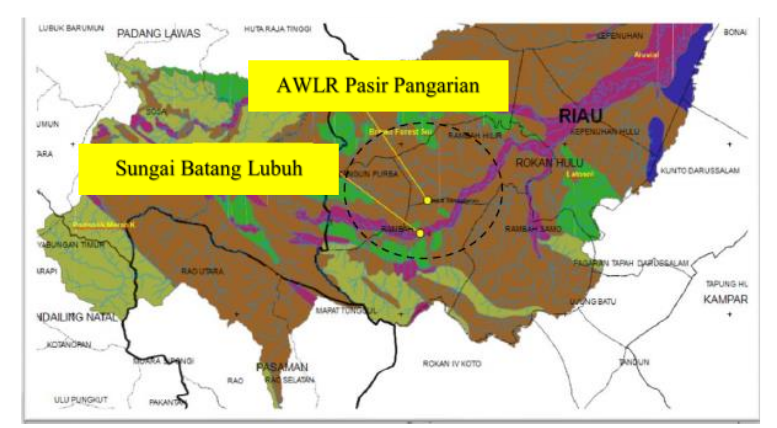

Gambar 2. Peta Lokasi Penelitian Sumber : [10]

Adapun prosedur yang terdapat dalam analisis ini adalah pengumpulan data dan memodelkan hidrologi menggunakan metode Soil Moisture Accounting (SMA) menggunakan sofware HEC-HMS. Prosedur Penelitian mengikuti alur secara garis besar sebagai berikut.

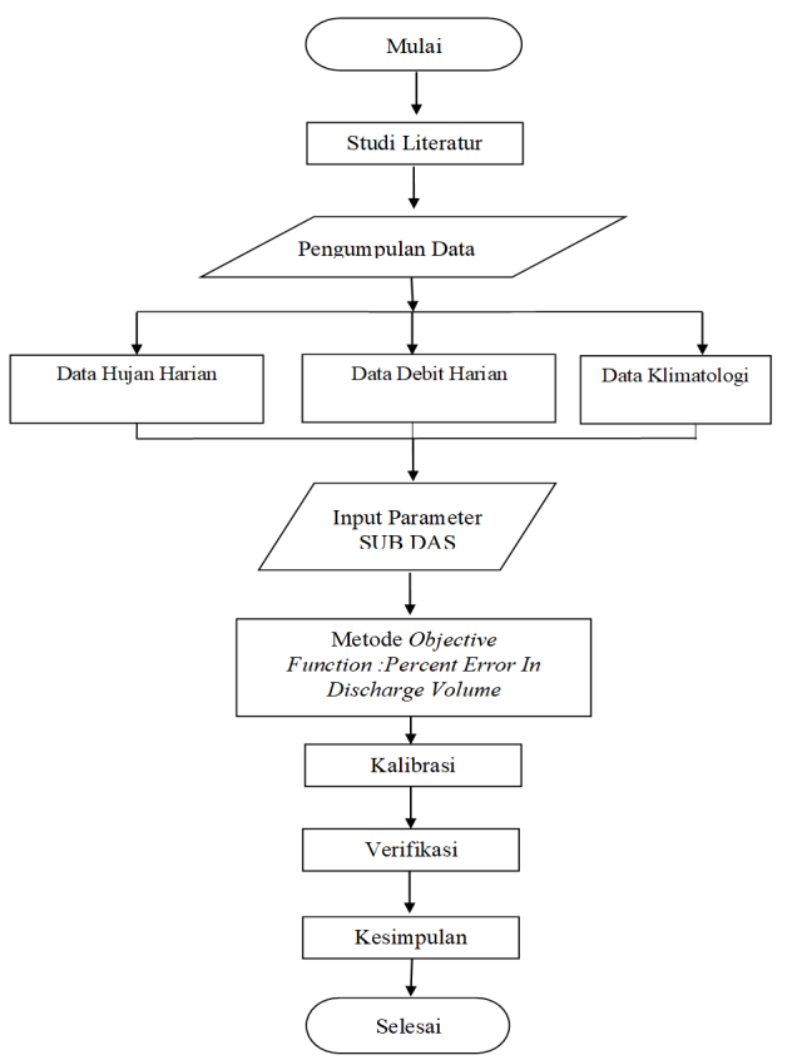

Gambar 3. Bagan Alir Penelitian

\section{Pengumpulan Data}

Pengumpulan data-data ini yang kemudian akan diolah untuk menarik suatu kesimpulan. Datadata yang diperoleh dari observasi lapangan antara lain adalah :

1. Data Curah Hujan

Dalam penelitian ini menggunakan data curah hujan harian di Stasiun Pasar Tangun tahun 2008 sampai 2017. Data Curah Hujan ini diperoleh dari Balai Wilayah Sungai Sumatera III Provinsi Riau. Interval data hujan yang diinput ke HEC-HMS 4.3 adalah data hujan interval harian.

\section{Data Debit}

Dalam penelitian ini menggunakan data elevasi dari AWLR di Stasiun Pasir Pengaraiantahun 2008 sampai 2017. Data debit ini diperoleh dari Balai Wilayah Sungai Sumatera III Provinsi Riau. Data elevasi yang satuan $\mathrm{cm}$ dikonversikan $\mathrm{m} 3 / \mathrm{s}$ menjadi debit dengan menggunakan rumus lengkung debit untuk AWLR stasiun pasir pengaraian. Contoh perhitungan dapat dilihat sebagai berikut untuk debit observasi tanggal 01 januari 2008:

$$
\begin{array}{ll}
\mathrm{Q} & =47,662 \mathrm{x}(\mathrm{H}-\llbracket 0.140) \rrbracket \wedge 1.950 \\
\mathrm{Q} & =47,662 \times(1.31-\llbracket 0.140) \rrbracket \wedge 1.950 \\
\mathrm{Q} & =64.734 \mathrm{~m} 3 / \mathrm{s}
\end{array}
$$

Dengan :

$\mathrm{Q}=$ Debit $(\mathrm{m} 3 / \mathrm{s})$

$\mathrm{H}=$ Elevasi Muka air (m)

\section{Data Klimatologi}

Dalam penelitian ini menggunakan data Klimatologi di Rambah Utama tahun 2008 sampai 2017. Data klimatologi ini diperoleh dari Balai Wilayah Sungai Sumatera III Provinsi Riau. Data klimatologi ini berupa kelembapan maksimum, kelembapan minimum, temperatur maksimum, temperatur minimum, penyiraman matahari dan kecepatan angin.

\section{HASIL DAN DISKUSI}

\section{Hasil Kalibrasi}

Kalibrasi pertama untuk skema VII dengan Panjang data 7 tahun yaitu tahun 2008-2014. Initial Value untuk parameter yang lain kecuali Recession Initial Discharge dan Recession - Recession Constant menggunakan nilai minimum. Hasil dari kalibrasi pertama untuk skema VII dapat dilihat pada Tabel 1. 
Tabel 1. Kalibrasi Pertama Skema VII

\begin{tabular}{|c|c|c|c|c|}
\hline Parameter & Sat. & Initial Value & $\begin{array}{l}\text { Optimized } \\
\text { Value }\end{array}$ & $\begin{array}{l}\text { Persentase } \\
\text { Perubahan }\end{array}$ \\
\hline $\begin{array}{l}\text { Clark Unit Hydrograph - Storage } \\
\text { Coefficient }\end{array}$ & HR & 0.02 & 0.28975 & $1294 \%$ \\
\hline $\begin{array}{l}\text { Clark Unit Hydrograph - Time of } \\
\text { Concentration }\end{array}$ & HR & 0.0167 & 0.22288 & $1104 \%$ \\
\hline Recession - Initial Discharge & M3/S & 64.734 & 73.965 & $11 \%$ \\
\hline Recession - Ratio to Peak & & 0 & 0.079017 & \\
\hline Recession - Recession Constant & & 0.95 & 0.96544 & $4 \%$ \\
\hline Simple Canopy - Initial Storage & $\%$ & 0.001 & 0.0645638 & $74 \%$ \\
\hline Simple Canopy - Max Storage & MM & 0.001 & 0.12284 & $4539 \%$ \\
\hline Simple Surface - Initial Storage & $\%$ & 0.001 & 0.15313 & $7938 \%$ \\
\hline Simple Surface - Max Storage & MM & 0.001 & 0.19195 & $7144 \%$ \\
\hline $\begin{array}{l}\text { Soil Moisture Accounting - GW1 } \\
\text { Percolation }\end{array}$ & $\mathrm{MM} / \mathrm{HR}$ & 0.01 & 0.21277 & $1035 \%$ \\
\hline Soil Moisture Accounting - GW1 Storage & MM & 0.01 & 0.21831 & $1309 \%$ \\
\hline $\begin{array}{l}\text { Soil Moisture Accounting - GW1 Storage } \\
\text { Coefficient }\end{array}$ & HR & 0.01 & 0.2181 & $1497 \%$ \\
\hline $\begin{array}{l}\text { Soil Moisture Accounting - GW2 } \\
\text { Percolation }\end{array}$ & $\mathrm{MM} / \mathrm{HR}$ & 0.01 & 0.51815 & $1608 \%$ \\
\hline Soil Moisture Accounting - GW2 Storage & MM & 0.01 & 0.45457 & $1565 \%$ \\
\hline $\begin{array}{l}\text { Soil Moisture Accounting - GW2 Storage } \\
\text { Coefficient }\end{array}$ & HR & 0.01 & 0.47325 & $1865 \%$ \\
\hline $\begin{array}{l}\text { Soil Moisture Accounting - Initial GW1 } \\
\text { Content }\end{array}$ & $\%$ & 0.001 & 0.40067 & $16400 \%$ \\
\hline $\begin{array}{l}\text { Soil Moisture Accounting - Initial GW2 } \\
\text { Content }\end{array}$ & $\%$ & 0.001 & 0.3371 & $16795 \%$ \\
\hline $\begin{array}{l}\text { Soil Moisture Accounting - Initial Soil } \\
\text { Content }\end{array}$ & $\%$ & 0.001 & 0.27352 & $16165 \%$ \\
\hline $\begin{array}{l}\text { Soil Moisture Accounting - Max } \\
\text { Infiltration }\end{array}$ & $\mathrm{MM} / \mathrm{HR}$ & 0.01 & 0.24137 & $1416 \%$ \\
\hline $\begin{array}{l}\text { Soil Moisture Accounting - Soil } \\
\text { Percolation }\end{array}$ & $\mathrm{MM} / \mathrm{HR}$ & 0.01 & 0.17779 & $1166 \%$ \\
\hline Soil Moisture Accounting - Soil Storage & MM & 0.01 & 0.11421 & $780 \%$ \\
\hline $\begin{array}{l}\text { Soil Moisture Accounting - Tension } \\
\text { Storage }\end{array}$ & MM & 0.01 & 0.0506348 & $345 \%$ \\
\hline
\end{tabular}

Berdasarkan Tabel 1 dapat dilihat bahwa parameter Soil Moisture Accounting - Initial GW1 Content terjadi perubahan yang paling besar diantara parameter lainnya sebesar 39967\%. Persentase perubahan dari nilai initial value ke optimized value sangat besar, maka perlu dilakukan percobaan kalibrasi selanjutnya untuk mendapatkan hasil yang optimal. Hasil pada kalibrasi pertama ini menunjukkan nilai percent error in discharge volume sebesar 10,1 \% yang berarti "Baik", persentase perbedaan volume debit dan debit puncak untuk simulasi dengan observasi kalibrasi pertama ini dapat dilihat pada Gambar 4.

\begin{tabular}{|l|c|c|c|c|}
\hline \multicolumn{1}{|c|}{ Volume Units: $\bigcirc$ MM $\bigcirc 1000$ M3 } \\
\hline Measure & Simulated & Observed & Difference & $\begin{array}{c}\text { Percent } \\
\text { Difference }\end{array}$ \\
\hline Volume (1000 M3) & 23466684.0 & 21316923.1 & 2149761.0 & 10.1 \\
\hline Peak Flow (M3/S) & 1267.7 & 786.2 & 481.5 & 61.2 \\
\hline Time of Peak & 02 May2011,00:00 & 07 Jun2008, 00:00 & & \\
\hline
\end{tabular}

Gambar 4. Output Dari Aplikasi HEC-HMS Untuk Optimization Trials Kalibrasi Pertama Skema VII

Kalibrasi pertama belum dikatakan optimal karena masih ada peluang untuk lebih optimal dengan terus melakukan kalibrasi. Initial Value yang digunakan untuk proses kalibrasi kedua adalah Optimized Value dari kalibrasi pertama. Hasil dari kalibrasi kedua dapat dilihat pada Tabel 2. 
Tabel 2. Kalibrasi Kedua Skema VII

\begin{tabular}{|c|c|c|c|c|}
\hline Parameter & Sat. & Initial Value & $\begin{array}{c}\text { Optimized } \\
\text { Value }\end{array}$ & $\begin{array}{l}\text { Persentase } \\
\text { Perubahan }\end{array}$ \\
\hline $\begin{array}{l}\text { Clark Unit Hydrograph - Storage } \\
\text { Coefficient }\end{array}$ & HR & 0.28975 & 0.62308 & $115 \%$ \\
\hline $\begin{array}{l}\text { Clark Unit Hydrograph - Time of } \\
\text { Concentration }\end{array}$ & HR & 0.22288 & 0.55621 & $150 \%$ \\
\hline Recession - Initial Discharge & M3/S & 73.965 & 98.62 & $33 \%$ \\
\hline Recession - Ratio to Peak & & 0.079017 & 0.079017 & $0 \%$ \\
\hline Recession - Recession Constant & & 0.96544 & 0.96544 & $0 \%$ \\
\hline Simple Canopy - Initial Storage & $\%$ & 0.0645638 & 0.0645638 & $0 \%$ \\
\hline Simple Canopy - Max Storage & $\mathrm{MM}$ & 0.12284 & 0.12284 & $0 \%$ \\
\hline Simple Surface - Initial Storage & $\%$ & 0.15313 & 0.15313 & $0 \%$ \\
\hline Simple Surface - Max Storage & MM & 0.19195 & 0.19195 & $0 \%$ \\
\hline $\begin{array}{l}\text { Soil Moisture Accounting - GW1 } \\
\text { Percolation }\end{array}$ & $\mathrm{MM} / \mathrm{HR}$ & 0.21277 & 0.21277 & $0 \%$ \\
\hline $\begin{array}{l}\text { Soil Moisture Accounting - GW1 } \\
\text { Storage }\end{array}$ & MM & 0.21831 & 0.21831 & $0 \%$ \\
\hline $\begin{array}{l}\text { Soil Moisture Accounting - GW1 } \\
\text { Storage Coefficient }\end{array}$ & HR & 0.2181 & 0.2181 & $0 \%$ \\
\hline $\begin{array}{l}\text { Soil Moisture Accounting - GW2 } \\
\text { Percolation }\end{array}$ & $\mathrm{MM} / \mathrm{HR}$ & 0.51815 & 0.51815 & $0 \%$ \\
\hline $\begin{array}{l}\text { Soil Moisture Accounting - GW2 } \\
\text { Storage }\end{array}$ & MM & 0.45457 & 0.45457 & $0 \%$ \\
\hline $\begin{array}{l}\text { Soil Moisture Accounting - GW2 } \\
\text { Storage Coefficient }\end{array}$ & HR & 0.47325 & 0.47325 & $0 \%$ \\
\hline $\begin{array}{l}\text { Soil Moisture Accounting - Initial GW1 } \\
\text { Content }\end{array}$ & $\%$ & 0.40067 & 0.40067 & $0 \%$ \\
\hline $\begin{array}{l}\text { Soil Moisture Accounting - Initial GW2 } \\
\text { Content }\end{array}$ & $\%$ & 0.3371 & 0.3371 & $0 \%$ \\
\hline $\begin{array}{l}\text { Soil Moisture Accounting - Initial Soil } \\
\text { Content }\end{array}$ & $\%$ & 0.27352 & 0.27352 & $0 \%$ \\
\hline $\begin{array}{l}\text { Soil Moisture Accounting - Max } \\
\text { Infiltration }\end{array}$ & $\mathrm{MM} / \mathrm{HR}$ & 0.24137 & 0.24137 & $0 \%$ \\
\hline $\begin{array}{l}\text { Soil Moisture Accounting - Soil } \\
\text { Percolation }\end{array}$ & $\mathrm{MM} / \mathrm{HR}$ & 0.17779 & 0.17779 & $0 \%$ \\
\hline Soil Moisture Accounting - Soil Storage & MM & 0.11421 & 0.11421 & $0 \%$ \\
\hline $\begin{array}{l}\text { Soil Moisture Accounting - Tension } \\
\text { Storage }\end{array}$ & $\mathrm{MM}$ & 0.0506348 & 0.0506348 & $0 \%$ \\
\hline
\end{tabular}

Berdasarkan Tabel 2 dapat dilihat bahwa parameter Clark Unit Hydrograph - Time of Concentration terjadi perubahan yang paling besar diantara parameter lainnya sebesar $278 \%$.

Persentase perubahan dari nilai initial value ke optimized value sangat besar, maka perlu dilakukan percobaan kalibrasi selanjutnya untuk mendapatkan hasil yang optimal. Hasil pada kalibrasi pertama menunjukkan nilai percent error in discharge volume sebesar 15,1 \% yang berarti "Sangat Baik", persentase perbedaan volume debit dan debit puncak untuk simulasi dengan observasi kalibrasi pertama ini dapat dilihat pada Gambar 5.

\begin{tabular}{l|c|c|c|c|}
\multicolumn{7}{c}{ Volume Units: $\bigcirc \mathrm{MM} \bigcirc 1000 \mathrm{M} 3$} \\
\hline \multicolumn{1}{|c|}{ Measure } & Simulated & Observed & Difference & $\begin{array}{c}\text { Percent } \\
\text { Difference }\end{array}$ \\
\hline Volume (1000 M3) & 18091309.7 & 21316923.1 & -3225613.4 & -15.1 \\
\hline Peak Flow (M3/S) & 1225.4 & 786.2 & 439.2 & 55.9 \\
\hline Time of Peak & 02 May2011, 00:00 & 07 Jun2008, 00:00 & & \\
\hline
\end{tabular}

Gambar 5. Output Dari Aplikasi HEC-HMS Untuk Optimization Trials Kalibrasi Kedua Skema VII

Kalibrasi kedua belum dikatakan optimal karena masih ada peluang untuk lebih optimal dengan terus melakukan kalibrasi. Initial Value yang digunakan untuk proses kalibrasi ketiga adalah Optimized Value dari kalibrasi kedua. Hasil dari kalibrasi ketiga dapat dilihat pada Tabel 3. 
Tabel 3. Kalibrasi Ketiga Skema VII

\begin{tabular}{|c|c|c|c|c|}
\hline Parameter & Sat. & Initial Value & $\begin{array}{l}\text { Optimized } \\
\text { Value }\end{array}$ & $\begin{array}{l}\text { Persentase } \\
\text { Perubahan }\end{array}$ \\
\hline $\begin{array}{l}\text { Clark Unit Hydrograph - Storage } \\
\text { Coefficient }\end{array}$ & HR & 0.62308 & 1.4925 & $115 \%$ \\
\hline $\begin{array}{l}\text { Clark Unit Hydrograph - Time of } \\
\text { Concentration }\end{array}$ & HR & 0.55621 & 1.1196 & $150 \%$ \\
\hline Recession - Initial Discharge & M3/S & 98.62 & 191.63 & $33 \%$ \\
\hline Recession - Ratio to Peak & & 0.079017 & & \\
\hline Recession - Recession Constant & & 0.96544 & & \\
\hline Simple Canopy - Initial Storage & $\%$ & 0.0645638 & & \\
\hline Simple Canopy - Max Storage & MM & 0.12284 & & \\
\hline Simple Surface - Initial Storage & $\%$ & 0.15313 & & \\
\hline Simple Surface - Max Storage & MM & 0.19195 & & \\
\hline $\begin{array}{l}\text { Soil Moisture Accounting - GW1 } \\
\text { Percolation }\end{array}$ & $\mathrm{MM} / \mathrm{HR}$ & 0.21277 & & \\
\hline $\begin{array}{l}\text { Soil Moisture Accounting - } G W 1 \\
\text { Storage }\end{array}$ & MM & 0.21831 & & \\
\hline $\begin{array}{l}\text { Soil Moisture Accounting - GW1 } \\
\text { Storage Coefficient }\end{array}$ & HR & 0.2181 & & \\
\hline $\begin{array}{l}\text { Soil Moisture Accounting - GW2 } \\
\text { Percolation }\end{array}$ & $\mathrm{MM} / \mathrm{HR}$ & 0.51815 & & \\
\hline $\begin{array}{l}\text { Soil Moisture Accounting - GW2 } \\
\text { Storage }\end{array}$ & MM & 0.45457 & & \\
\hline $\begin{array}{l}\text { Soil Moisture Accounting - GW2 } \\
\text { Storage Coefficient }\end{array}$ & HR & 0.47325 & & \\
\hline $\begin{array}{l}\text { Soil Moisture Accounting - Initial GW1 } \\
\text { Content }\end{array}$ & $\%$ & 0.40067 & & \\
\hline $\begin{array}{l}\text { Soil Moisture Accounting - Initial GW2 } \\
\text { Content }\end{array}$ & $\%$ & 0.3371 & & \\
\hline $\begin{array}{l}\text { Soil Moisture Accounting - Initial Soil } \\
\text { Content }\end{array}$ & $\%$ & 0.27352 & & \\
\hline $\begin{array}{l}\text { Soil Moisture Accounting - Max } \\
\text { Infiltration }\end{array}$ & $\mathrm{MM} / \mathrm{HR}$ & 0.24137 & & \\
\hline $\begin{array}{l}\text { Soil Moisture Accounting }- \text { Soil } \\
\text { Percolation }\end{array}$ & MM/HR & 0.17779 & & \\
\hline Soil Moisture Accounting - Soil Storage & MM & 0.11421 & & \\
\hline $\begin{array}{l}\text { Soil Moisture Accounting - Tension } \\
\text { Storage }\end{array}$ & MM & 0.0506348 & & \\
\hline
\end{tabular}

Hasil kalibrasi kedua ini menunjukkan nilai objective function percent error in discharge volume sebesar 0,0\% yang berarti "Sangat Baik". Persentase perbedaan volume debit dan debit puncak untuk simulasi dengan observasi kalibrasi kedua ini dapat dilihat pada Gambar 6.

\begin{tabular}{|l|c|c|c|c|}
\hline \multicolumn{1}{|c}{ Volume Units: $O$ MM 01000 M3 } \\
\hline Measure & Simulated & Observed & Difference & $\begin{array}{c}\text { Percent } \\
\text { Difference }\end{array}$ \\
\hline Volume (1000 M3) & 21328800.1 & 21316923.1 & 11877.0 & 0.1 \\
\hline Peak Flow (M3/S) & 1255.4 & 786.2 & 469.2 & 59.7 \\
\hline Time of Peak & 02 May2011, 00:00 07 Jun2008, 00:00 & \\
\hline \multicolumn{5}{|l|}{} \\
\hline
\end{tabular}

Gambar 6. Output Dari Aplikasi HEC-HMS Untuk Optimization Trials Kalibrasi Ketiga Skema VII
Hasil dari percobaan kalibrasi pada skema VII menunjukkan kalibrasi kedua yang paling optimal sebesar 0,1 \% dibandingkan dengan kalibrasi kedua sebesar 2,7\%. Hasil Output HEC-HMS untuk kalibrasi pada skema VII (7 tahun kalibrasi) ini menunjukan hasil Percent error in Discharge Volume yang sangat baik. Perbandingan grafik debit simulasi dengan debit observasi untuk Percent error in Discharge Volume sebesar 2,7\% dapat dilihat pada Gambar 7. 


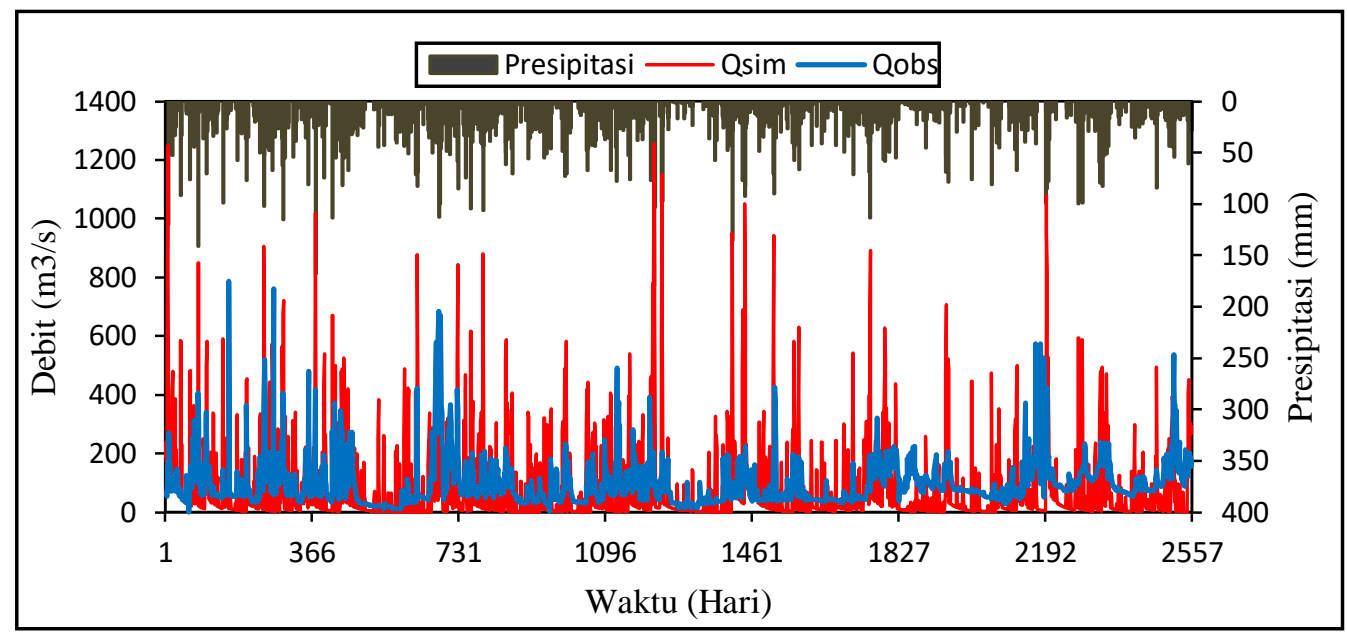

Gambar 7. Hidrograf Hujan, Kalibrasi Debit Observasi vs Debit Simulasi Skema VII

\section{Hasil Verifikasi}

Nilai paramater yang diinput ke dalam program HEC-HMS untuk proses verifikasi ialah nilai yang paling optimal (optimized value) dari kalibrasi untuk masing-masing skema. Nilai yang telah diperoleh dari hasil yang paling optimal dari kalibrasi selanjutnya dilakukan running untuk melihat prediksi nilai debit pada tahun yang akan datang dari tahun data saat kalibrasi. Metode Objective Function untuk verifikasi sama dengan kalibrasi menggunakan Percentage error in Discharge volume. Berikut hasil dari verfikasi dari semua skema dan contoh perhitungan dapat dilihat pada Tabel 4.

Tabel 4. Rekapitulasi Hasil Verifikasi

\begin{tabular}{|c|c|c|c|c|}
\hline Skema & $\begin{array}{c}\text { Volume } \\
\text { observasi } \\
\left(\mathrm{m}^{3}\right)\end{array}$ & $\begin{array}{c}\text { Volume } \\
\text { Simulasi } \\
\quad\left(\mathrm{m}^{3}\right)\end{array}$ & PEV & Keterangan \\
\hline $\begin{array}{c}\text { Skema } 1 \\
\text { (9 tahun Verifikasi) }\end{array}$ & 26523970.8 & 22207403.5 & 16,3 & Memuaskan \\
\hline $\begin{array}{c}\text { Skema } 2 \\
\text { (8 tahun Verifikasi) }\end{array}$ & 23304782.1 & 18411663.7 & 21,0 & Memuaskan \\
\hline $\begin{array}{c}\text { Skema } 3 \\
\text { ( } 7 \text { tahun Verifikasi) }\end{array}$ & 20890525.8 & 15576024.9 & 25,5 & Tidak Memuaskan \\
\hline $\begin{array}{c}\text { Skema } 4 \\
\text { (6 tahun Verifikasi) }\end{array}$ & 18285495 & 12904260 & 29,4 & Tidak Memuaskan \\
\hline $\begin{array}{c}\text { Skema } 5 \\
\text { (5 tahun Verifikasi) }\end{array}$ & 15757009.3 & 10398356 & 34 & Tidak Memuaskan \\
\hline $\begin{array}{c}\text { Skema } 6 \\
\text { (4 tahun Verifikasi) }\end{array}$ & 12408619.7 & 10154478.9 & 18,2 & Memuaskan \\
\hline $\begin{array}{c}\text { Skema } 7 \\
\text { (3 tahun Verifikasi) }\end{array}$ & 8470913.5 & 7565497.9 & 10,7 & Baik \\
\hline $\begin{array}{c}\text { Skema } 8 \\
\text { (2 tahun Verifikasi) }\end{array}$ & 5456656.2 & 4255308.3 & 22,1 & Memuaskan \\
\hline $\begin{array}{c}\text { Skema } 9 \\
\text { (1 tahun Verifikasi) }\end{array}$ & 3041854.8 & 4498221.4 & 48 & Tidak Memuaskan \\
\hline
\end{tabular}

\section{KESIMPULAN}

Berdasarkan penelitian yang berjudul "Analisis Model Hidrologi menggunakan Soil Moisture Accounting" (studi kasus : SUB DAS Stasiun Pasir Pangaraian"), maka dapat diambil kesimpulan bahwa berdasarkan sembilan skema dengan perolehan Percent error in discharge volume (PEV) yang paling optimum pada tahap verfikasi dipilih skema VII Panjang data 7 tahun kalibrasi 3 tahun verifikasi dapat mewakili karakteristik DAS sebenarnya, dengan hasil PEV untuk kalibrasi $0,0 \%$ "Sangat Baik" dan verifikasi 10,1\% "Baik" dan berdasarkan Hidrograf hujan pada tahap kalibrasi dan tahap verifikasi menunjukkan bahwa Percent error in discharge volume (PEV) mengoptimalkan volume dengan mengurangi parameter baseflownya sebagai setiap waktu baseflow-nya mendekati ordinary nol. 


\section{REFERENSI}

[1] R. Karno and J. Mubarrak, "ANALISIS SPASIAL (EKOLOGI) PEMANFAATAN DAERAH ALIRAN SUNGAI (DAS) DI SUNGAI BATANG LUBUH KECAMATAN RAMBAH KABUPATEN ROKAN HULU," Edu Res., vol. 7, no. 1, 2018.

[2] N. A. Affandy and N. Anwar, "Pemodelan HujanDebit Menggunakan Model HEC-HMS di DAS Sampean Baru," Surabaya Inst. Teknol. Sepuluh Sept., 2007.

[3] T. Marhendi, "ANALISIS LOW FLOW MENGGUNAKAN MODEL HEC-HMS 3.1 UNTUK KASUS SUB DAS KRANGGAN," Sainteks, vol. 11, no. $1,2014$.

[4] Suripin, Sistem Drainase Perkotaan yang Berkelanjutan. Andi, 2004.

[5] B. Triatmodjo and H. Terapan, "Beta Offset." Yogyakarta, 2008.

[6] U. S. A. C. O. Engineers, "Hydrologic Modeling System HEC-HMS, Technical Reference Manual," California, USA, 2000.

[7] R. Munajad and S. Suprayogi, "Kajian Hujanaliran Menggunakan Model Hec-hms di Sub Daerah Aliran Sungai Wuryantoro Wonogiri, Jawa Tengah," J. Bumi Indones., vol. 4, no. 1, 2015.

[8] D. D. Utami and G. D. Wibowo, "Analisa Ketersediaan Air Dengan menggunakan Gabungan Metode Mock Dan Model Tank Di Kali Samin Kabupaten Karanganyar." Universitas Muhammadiyah Surakarta, 2016.

[9] H. Fardian, S. SUTOKNO, and M. Fauzi, "PENGGUNAAN DATA HUJAN SATELIT TERKOREKSI UNTUK ANALISIS KEJADIAN BANJIR DI DAS ROKAN," RACIC J. Tek. Sipil Univ. Abdurrab, vol. 2, no. 02, pp. 233-247, 2017.

[10] Y. Lilis Handayani, B. Sujatmoko, and G. Oktavia, "Stream's regime coefficient in upstream Rokan watershed of Riau Province," in MATEC Web of Conferences, 2019, vol. 276, p. 4013. 